\title{
ФОРМУВАННЯ ПРОДУКТИВНИХ ЯКОСТЕЙ ОВЕЦЬ АСКАНІЙСЬКОЇ ТОНКОРУННОЇ ПОРОДИ ТАВРІЙСЬКОГО ТИПУ ЗАЛЕЖНО ВІД ПОХОДЖЕННЯ
}

\author{
Нежлукченко Тетяна Іванівна \\ Миколаївський національний аграрний університет \\ доктор сільськогосподарських наук, професор \\ ORCID: 0000-0001-5997-2355 \\ E-mail: tekhnolohiivpt@gmail.com \\ Нежлукченко Наталя Валентинівна \\ кандидат сільськогосподарських наук, доцент \\ дП ДГ «Асканійське» Каховського району, Херсонської області \\ ORCID: 0000 - 0003-4871- 8743 \\ E-mail: nataly12154@gmail.com \\ Заруба Костянтин Віталійович \\ кандидат сільськогосподарських. наук, с.н.с. \\ Інститут тваринництва степових районів ім. М.Ф. Іванова «Асканія -Нова» \\ ORCID: 0000-0002-9058-7751 \\ E-mail: zaruba.kos@gmail.com \\ Рубцов Ігор Олександрович \\ кандидат сільськогосподарських наук, доцент \\ Сумський національний аграрний університет \\ ORCID: 0000-0002-7591-5905 \\ E-mail: rubtsov igor68@ukr.net
}

Отримана базова інфрормація щодо закономірностей росту та розвитку овець та формування їх продуктивних якостей залежно від їх лінійного походження та впливу спадковості баранів-плідників. Уперше в умовах племзаводу, залежно від лінійного походження, проведено порівняльну оцінку овець асканійської тонкорунної породи таврійського типу за показниками росту, розвитку та вовнової продуктивності. Визначено генетичний потенціал ліній за ознаками продуктивності та ступінь їх реалізації в процесі онтогенезу. За вовновою продуктивністю спостерігаються високі та середні значення у різних статево-вікових групах овець залежно від їх лінійної належності. Удосконалення цього показника можливо здійснювати з максимальним використанням у селекції популяції овець племзаводу внутрішньолінійних поєднань тварин ліній № №227, 369, 375, 0517, 1444. В умовах племзаводу доцільно використовувати овець, що належить цим лініям для отримання додаткової продукції.

Ключові слова: асканійська тонкорунна порода, таврійський тип, ріст, розвиток, вовнова продуктивність, лінії.

DOI: https://doi.org/10.32845/bsnau.Ivst.2021.4.32

Вівчарство $є$ невід'ємною частиною світового сільськогосподарського виробництва, що спричинено широкою різноманітністю продуктивних можливостей і адаптивною здатністю овець. Степову зону України можна вважати зоною вівчарства, оскільки тут зосереджено понад 75\% овець від загальної їх кількості. Цьому сприяє наявність великих площ сільськогосподарських угідь, тривалий період пасовищного утримання, дешеві концентровані корми та велика кількість відходів від переробки продукції рослинництва. Слід відмітити, що вівці серед інших сільськогосподарських тварин, найменше потребують спеціального догляду, споживають практично всі види рослинності, перетворюючи її на корисні для людини продукти - молоко і молочні продукти, м'ясо, вовну, жир тощо [1, 2, 3].

На сучасному етапі вимоги, що пред'являються до генетичних якостей сільськогосподарських тварин, зростають [4]. Племінна робота з тонкорунними вівцями направлена на створення нових типів, ліній, які забезпечують отримання від однієї вівці в середньому 3,2-3,5 кг митої вовни. Лінії дещо ізольовані, але своїм походженням і перспективою розвитку органічно пов'язані з історією та долею поро-

ди. Такий тип розведення дозволяє ефективно використовувати індивідуальні особливості кращих тварин і перетворювати їх у групові, створювати генетичну диференціацію породи, використовуючи яку в системі підбору можна отримувати високоякісних тварин. Тому цей метод - основа племінної роботи племзаводів. Увага дослідників і направлена на визначення впливу умов середовища, на реакцію окремих генотипів і ліній тварин на зміну паратипових факторів, на реалізацію генетичного потенціалу та надбання групами тварин певних адаптаційних здатностей $[5,6,7]$.

Подальше підвищення ефективності галузі вівчарства базується не тільки на додаткових капіталовкладеннях, удосконаленні технологічних прийомів, але й на використанні сучасних методів розведення і селекції для одержання якісної вовни та збільшення її настригу. Робота з удосконалення і використання специсіки ліній за походженням і продуктивністю забезпечує не тільки структурну дифереціацію стада за груповими спадковими задатками овець щодо їх господарсько-корисними ознаками, але й забезпечує структуровану упорядкованість системи відбору і підбору тварин у стаді [8].

Вісник Сумського національного аграрного університету 
I тому останнім часом увага дослідників направлена на питання впливу умов середовища, оскільки спадкові можливості в процесі розвитку організму не завжди повною мірою реалізується, бо залежить від зовнішніх фракторів. Такий підхід дозволить враховувати вплив взаємодії «генотип $\mathrm{x}$ середовище» на реалізацію генетичного потенціалу продуктивності, а також оцінити реакцію окремих генотипів або ліній на зміну умов середовища [9].

Метою досліджень $€$ вивчення впливу лінійної належності овець асканійської тонкорунної породи таврійського типу в умовах племзаводу на рівень їх продуктивності та формування росту та розвитку.

Відповідно до мети досліджень вирішувалися наступні завдання :

- проаналізувати динаміку живої маси молодняку овець;

- порівняти показники живої маси овець різних статево-вікових груп різного походження за лініями;

- дослідити вовнову продуктивність овець різних лі- ній асканійської тонкорунної породи таврійського типу;

Матеріали та методи досліджень. Дослідження проведені на вівцях асканійської тонкорунної породи таврійського типу племзаводу ДП ДГ «Асканійське» Каховського району Херсонської області. Використано комплекс загальноприйнятих методів : системного аналізу й узагальнення, зоотехнічних, лабораторно-аналітичних, обліковорозрахункових. Живу масу і довжину штапелю у тварин визначали при бонітуванні, вовнову продуктивність овець враховували в період стриження з використанням методик ВІТ та ВАСХНІЛ [10]. Обробка даних здійснено згідно методів варіаційної статистики за М.О. Плохінським [11].

Результати досліджень. Вивчено закономірності росту та розвитку молодняку овець 2020 року народження (ярки та баранчики), проведено бонітування дорослих овець попереднього року народження (переярки) та дорослих баранів. Проведено порівняльну оцінку живої маси тварин (табл. 1).

Таблиця 1

Жива маса овець ДП ДГ «Асканійське» залежно від лінійної належності

\begin{tabular}{|c|c|c|c|c|c|c|c|c|}
\hline \multirow[b]{2}{*}{ Лінії } & \multicolumn{2}{|r|}{ ЯркИ } & \multicolumn{2}{|c|}{ Переярки } & \multicolumn{2}{|c|}{ Барани-річняки } & \multicolumn{2}{|c|}{ Дорослі барани } \\
\hline & $n$ & $\begin{array}{c}\text { жива маса, } \\
\text { кट }\end{array}$ & $n$ & $\begin{array}{c}\text { жива маса, } \\
\text { ке }\end{array}$ & $n$ & $\begin{array}{c}\text { жива маса, } \\
\text { кг }\end{array}$ & $n$ & $\begin{array}{c}\text { жива маса, } \\
\text { кट }\end{array}$ \\
\hline 224 & 21 & $59,9 \pm 1,30$ & 60 & $70,2 \pm 1,06$ & 17 & $74,0 \pm 1,84$ & 18 & $110,0 \pm 2,06$ \\
\hline 227 & 32 & $56,9 \pm 0,97$ & 43 & $69,6 \pm 0,99$ & 13 & $73,1 \pm 1,10$ & 18 & $110,3 \pm 2,16$ \\
\hline 369 & 26 & $56,8 \pm 0,98$ & 67 & $68,5 \pm 0,91$ & 9 & $72,8 \pm 1,86$ & 19 & $100,4 \pm 1,79$ \\
\hline 375 & 38 & $58,1 \pm 0,94$ & 50 & $70,9 \pm 0,96$ & 23 & $72,2 \pm 1,71$ & 17 & $98,8 \pm 2,22$ \\
\hline 0058 & 50 & $57,4 \pm 0,67$ & 48 & $70,8 \pm 1,24$ & 10 & $72,9 \pm 2,60$ & 24 & $101,0 \pm 1,55$ \\
\hline 0517 & 35 & $56,6 \pm 0,72$ & 35 & $70,6 \pm 1,24$ & 19 & $76,7 \pm 1,22$ & 10 & $101,4 \pm 0,96$ \\
\hline 1444 & 34 & $57,3 \pm 0,82$ & 49 & $71,2 \pm 1,15$ & 15 & $73,0 \pm 1,65$ & 14 & $100,5 \pm 2,75$ \\
\hline 1577 & 38 & $57,9 \pm 0,88$ & 52 & $67,5 \pm 0,86$ & 21 & $72,7 \pm 1,46$ & 7 & $102,4 \pm 3,16$ \\
\hline Середнє & 274 & $57,1 \pm 0,32$ & 404 & $69,5 \pm 0,35$ & 127 & $73,3 \pm 0,58$ & 131 & $103,4 \pm 0,80$ \\
\hline
\end{tabular}

Так, серед ярок із восьми поєднань, найвищі показники живої маси спостерігалися у ярок за лінійним походженням від лінії № 224 - 59,9 кг, тоді як найнижчі - у ярок лінії № 0517 - 56,6 кг. На рівні середнього значення $(57,1$ кг) мали ярки ліній №№ 0058.та 1444. Перевага за живою масою не суттєва і не достовірна, тому за цим показником міжлінійної різниці не спостерігається.

Жива маса переярок була на 12,4 кг вища, ніж у ярок, що більше на 17,1\% . Переярка з максимальною живою масою була походженням 3 лінії № 1444 (71,2 кг), а найнижча - у тварин лінії № 369. Аналогії з показниками за живою масою у ярок майже не спостерігається, виняток тільки у тварин лінії № 0058, які мали живу масу на рівні середнього значення - 70,8 кг, що спостерігається й у ярок.

Щодо живої маси баранчиків-річняків то тої закономірності, що була у ярок у розрізі ліній не спостерігалося і стверджувати про високий рівень спадковості за цією ознакою не має підстави. Адже найвищу живу масу мали баранці лінії № 0517 - 76,7 кг, а найнижчу - тварини лінії № 375 72,2 кг. На рівні середнього значення (73,3 кг) живу масу мали тварини ліній № № 227 та 1477. Тобто, стабільні середні показники за живою масою спостерігаються як у ярок, так і баранчиків-річняків тільки за походженням за лінією №1444. Статевий диморфізм суттєво проявляється в даному віці тварин і складає понад 22\%, що закономірно для овець річного віку.
Жива маса дорослих баранів-плідників у розрізі ліній схожа на загальні показники баранців-річняків, але найвища жива маса характерна тваринам лінії № 227 - 110,3 кг, а найнижча у тварин із лінії №№ $369(100,4$ кг) та 1444 (100,5 кг). Закономірну стабільність на рівні середніх значень знову підтвердили вівці за походженням від поєднань за лінією № $1444-100,5$ кг.

Таким чином, можна стверджувати, що за селекційною ознакою «жива маса» у овець різних статево-вікових груп спостерігається деяка закономірність, а саме вівці походженням за лінією № 1444 мають стабільні високі та середні значення за цією ознакою. Тільки у самців, тобто баранів-річняків та дорослих баранів, які мають походження від поєднань за лінією № 375 стабільно спостерігаються найнижчі значення за живою масою.

За показниками інтенсивності росту молодняку таврійського типу залежно від лінійної належності (табл. 2), встановлено, що середньодобовий приріст в середньому складає 193 г. Вищі показники характерні для тварин лінії № 227 - 201 г. Натомість у овець лінії № 1444 спостерігаються дещо нижчі прирості - 172 г.

В цілому у овець лінії № 227 також відмічається кращий абсолютний та відносний прирости на рівні 25,4 кг та $145,7 \%$. Зазначені показники у молодняку в середньому складають 23,1 кг та 141,9 \%. Дещо нижчі показники у лініях №№ 224 та 1444. 
Показники інтенсивності росту молодняку таврійського

Таблиця 2 типу від народження до 4-місячного віку

\begin{tabular}{|c|c|c|c|c|c|}
\hline \multirow{2}{*}{ Лінія } & \multirow{2}{*}{$n$} & \multicolumn{3}{|c|}{ Приріст } & \multirow{2}{*}{ Коефріцієнт росту } \\
\hline & & середньодобовий,г & абсолютний,кг & відносний,\% & \\
\hline 224 & 44 & $173 \pm 0,05$ & $19,8 \pm 0,79$ & 136,8 & 5,98 \\
\hline 227 & 30 & $201 \pm 0,04$ & $25,4 \pm 0,58$ & 145,7 & 6,18 \\
\hline 369 & 32 & $184 \pm 0,07$ & $21,7 \pm 0,60$ & 137,6 & 5,94 \\
\hline 375 & 30 & $197 \pm 0,02$ & $23,9 \pm 0,57$ & 144,4 & 6,10 \\
\hline 0058 & 53 & $191 \pm 0,02$ & $22,8 \pm 0,55$ & 141,1 & 6,00 \\
\hline 0517 & 48 & $199 \pm 0,05$ & $23,8 \pm 0,87$ & 143,7 & 6,09 \\
\hline 1444 & 21 & $172 \pm 0,03$ & $20,1 \pm 0,77$ & 135,6 & 5,82 \\
\hline 1577 & 29 & $188 \pm 0,04$ & $22,3 \pm 0,63$ & 137,9 & 5,98 \\
\hline Середнє & 287 & $193 \pm 0,01$ & $23,1 \pm 0,49$ & 141,9 & 6,04 \\
\hline
\end{tabular}

Було визначено рівень вовнової продуктивності тварин залежно від лінійного походження. Вовнова продуктивність ярок, переярок, баранів - річників та дорослих баранів представлена в таблицях 3-6.

Із восьми лінійних поєднань ярок найкращі показники за виходом чистої вовни та її настригом мали тварини лінії
№ 369, а найнижчі - у ярок лінії № 0058 (табл. 3).

у переярок середній настриг митої вовни складає 4,27 кг. Вищі показники спостерігаються у тварин лінії № 227 (4,47 кг), а нижчі у лінії № 375 (4,14 кг). Показники виходу чистої вовни у переярок високі і у різних ліній коливаються в незначних межах 56,9-57,9 \% (табл.4).

Таблиця 3

Вовнова продуктивність ярок

\begin{tabular}{|c|c|c|c|c|c|}
\hline Лінія & $\mathrm{n}$ & Довжина вовни, см & Настриг немитої вовни, кг & Вихід чистої вовни, $\%$ & Настриг чистої вовни, кг \\
\hline 224 & 21 & $12,7 \pm 0,23$ & $6,9 \pm 0,30$ & 55,9 & $3,86 \pm 0,27$ \\
\hline 227 & 32 & $12,5 \pm 0,20$ & $7,1 \pm 0,22$ & 56,2 & $3,99 \pm 0,16$ \\
\hline 369 & 26 & $12,4 \pm 0,23$ & $6,9 \pm 0,24$ & 60,1 & $4,15 \pm 0,19$ \\
\hline 375 & 38 & $12,9 \pm 0,21$ & $7,0 \pm 0,19$ & 54,7 & $3,83 \pm 0,13$ \\
\hline 0058 & 50 & $12,5 \pm 0,15$ & $6,4 \pm 0,14$ & 59,8 & $3,69 \pm 0,13$ \\
\hline 0517 & 35 & $13,1 \pm 0,21$ & $7,1 \pm 0,18$ & 57,6 & $3,91 \pm 0,14$ \\
\hline 1444 & 34 & $12,8 \pm 0,19$ & $6,6 \pm 0,19$ & 57,6 & $3,80 \pm 0,18$ \\
\hline 1577 & 38 & $12,6 \pm 0,18$ & $7,1 \pm 0,17$ & 56,9 & $4,04 \pm 0,11$ \\
\hline Середнє & 274 & $12,7 \pm 0,06$ & $6,8 \pm 0,06$ & 57,2 & $3,89 \pm 0,05$ \\
\hline
\end{tabular}

Вовнова продуктивність баранів-річників (табл. 5) | результати за тваринами походженням від лінії № 0517, а от дуже відрізняється від показників ярок і переярок, найкращі

Таблиця 4

Вовнова продуктивність переярок

\begin{tabular}{|c|c|c|c|c|c|}
\hline Лінія & $\mathrm{n}$ & Довжина вовни, см & Настриг немитої вовни, кг & Вихід чистої вовни, \% & Настриг чистої вовни, кг \\
\hline 224 & 60 & $9,5 \pm 0,14$ & $7,4 \pm 0,16$ & 57,4 & $4,25 \pm 0,09$ \\
\hline 227 & 43 & $9,5 \pm 0,16$ & $7,8 \pm 0,12$ & 57,3 & $4,47 \pm 0,07$ \\
\hline 369 & 67 & $9,7 \pm 0,11$ & $7,5 \pm 0,11$ & 56,9 & $4,27 \pm 0,06$ \\
\hline 375 & 50 & $9,9 \pm 0,13$ & $7,2 \pm 0,15$ & 57,6 & $4,15 \pm 0,09$ \\
\hline 0058 & 48 & $9,7 \pm 0,13$ & $7,5 \pm 0,14$ & 57,8 & $4,34 \pm 0,08$ \\
\hline 0517 & 35 & $10,2 \pm 0,14$ & $7,4 \pm 0,12$ & 57,6 & $4,26 \pm 0,07$ \\
\hline 1444 & 49 & $9,9 \pm 0,15$ & $7,5 \pm 0,13$ & 57,4 & $4,31 \pm 0,08$ \\
\hline 1577 & 52 & $10,0 \pm 0,13$ & $7,4 \pm 0,13$ & 57,9 & $4,29 \pm 0,07$ \\
\hline Середнє & 404 & $9,8 \pm 0,04$ & $7,4 \pm 0,04$ & 57,7 & $4,27 \pm 0,02$ \\
\hline
\end{tabular}

Вовнова продуктивність баранів-річняків

Таблиця 5

\begin{tabular}{|c|c|c|c|c|c|}
\hline Лінія & $\mathrm{n}$ & Довжина вовни, см & Настриг немитої вовни, кг & Вихід чистої вовни, \% & Настриг чистої вовни, кг \\
\hline 224 & 17 & $13,5 \pm 0,19$ & $8,6 \pm 0,45$ & 58,7 & $5,05 \pm 0,41$ \\
\hline 227 & 13 & $13,3 \pm 0,40$ & $8,6 \pm 0,38$ & 50,8 & $4,37 \pm 0,20$ \\
\hline 369 & 9 & $13,1 \pm 0,26$ & $8,9 \pm 0,54$ & 56,3 & $5,18 \pm 0,26$ \\
\hline 375 & 23 & $13,1 \pm 0,25$ & $8,3 \pm 0,20$ & 60,0 & $4,98 \pm 0,13$ \\
\hline 0058 & 10 & $13,6 \pm 0,35$ & $7,9 \pm 0,38$ & 53,3 & $4,22 \pm 0,38$ \\
\hline 0517 & 19 & $13,6 \pm 0,24$ & $8,8 \pm 0,23$ & 61,6 & $5,16 \pm 0,07$ \\
\hline 1444 & 15 & $13,3 \pm 0,25$ & $8,5 \pm 0,28$ & 56,2 & $4,78 \pm 0,42$ \\
\hline 1577 & 21 & $12,8 \pm 0,24$ & $8,5 \pm 0,20$ & 60,2 & $4,53 \pm 0,19$ \\
\hline Середнє & 127 & $13,2 \pm 0,09$ & $8,5 \pm 0,10$ & 56,2 & $4,78 \pm 0,10$ \\
\hline
\end{tabular}

Настриг немитої та чистої вовни у дорослих баранів - плідників у розрізі ліній : найвищі характерні тваринам ліній №№ 1444 та 375. Як у баранів -річняків, так і у дорос- лих плідників найнижчі значення настригів спостерігаються за лінією № 0058.

Таким чином, можна констатувати, що за вовновою 
продуктивністю вівці різних статево-вікових груп мають середні та високі значення за цією ознакою від різних поєднань за походження за лініями. Тільки ярки, барани-річняки та дорослі барани за лінією № 0058 мають найнижчі значення за довжиною, настригами немитої і чистої вовни та відсотком виходу чистої вовни.

Вовнова продуктивність дорослих баранів

Таблиця 6

\begin{tabular}{|c|c|c|c|c|c|}
\hline Лінія & $\mathrm{n}$ & Довжина вовни, см & Настриг немитої вовни, кг & Вихід чистої вовни, $\%$ & Настриг чистої вовни, кг \\
\hline 224 & 18 & $11,2 \pm 0,23$ & $11,1 \pm 0,31$ & 59,5 & $6,61 \pm 0,23$ \\
\hline 227 & 18 & $11,1 \pm 0,21$ & $11,4 \pm 0,37$ & 55,5 & $6,33 \pm 0,58$ \\
\hline 369 & 19 & $11,3 \pm 0,24$ & $11,1 \pm 0,35$ & 56,7 & $6,30 \pm 0,46$ \\
\hline 375 & 17 & $11,3 \pm 0,25$ & $11,4 \pm 0,34$ & 61,7 & $7,04 \pm 0,48$ \\
\hline 0058 & 24 & $11,2 \pm 0,26$ & $11,5 \pm 0,31$ & 54,1 & $6,23 \pm 0,55$ \\
\hline 0517 & 10 & $11,3 \pm 0,39$ & $11,4 \pm 0,62$ & 55,2 & $6,30 \pm 0,31$ \\
\hline 1444 & 14 & $11,9 \pm 0,34$ & $11,6 \pm 0,52$ & 54,1 & $6,28 \pm 0,55$ \\
\hline 1577 & 7 & $11,4 \pm 0,63$ & $11,5 \pm 0,38$ & 57,5 & $6,61 \pm 0,59$ \\
\hline Середнє & 131 & $11,3 \pm 0,09$ & $11,4 \pm 0,13$ & 57,6 & $6,57 \pm 0,16$ \\
\hline
\end{tabular}

Висновки. Уперше в умовах племзаводу, залежно від лінійного походження, проведено порівняльну оцінку овець асканійської тонкорунної породи таврійського типу за показниками росту, розвитку та вовнової продуктивності. Визначено генетичний потенціал ліній за ознаками продуктивності та ступінь їх реалізації в процесі онтогенезу.

Отримана базова інформація щодо закономірностей росту та розвитку овець та формування їх продуктивних якостей залежно від їх лінійного походження та впливу спадковості баранів-плідників. Установлено, що за живою масою у овець різних статево-вікових груп спостерігалися деякі закономірності, а саме вівці походженням за лінією №1444 мають стабільні високі та середні значення, найнижчі - від поєднань за лініями №№ 375 та 0058. За показниками інтенсивності росту молодняку таврійського типу залежно від

лінійної належності встановлено, що середньодобовий приріст в середньому складає 193г. Вищі показники характерні для всіх тварин лінії № 227 - 201г. У овець лінії № 227 також відмічаються кращі прирости: абсолютний - 25,4кг та відносний - 145,7 \%. Зазначені показники в середньому складають 23,1 кг та 141,9\%.

За вовновою продуктивністю спостерігаються високі та середні значення у різних статево-вікових групах овець залежно від їх лінійної належності. Удосконалення цього показника можливо здійснювати з максимальним використанням у селекції популяції овець племзаводу внутрілінійних поєднань тварин ліній №№ 227, 369, 375, 0517,1444. В умовах племзаводу доцільно використовувати овець, що належить цим лініям для отримання додаткової продукції.

\section{Список використаної літератури:}

45

1. Крилова О., Заруба К. Асканійська тонкорунна порода, внутріпородний тип. Тваринництво України , 2012,№8, С. 42 -

2. Сухарлєв В.А., Яковлев К.И.; Овцы Украины: [Монография] / под ред. В.А. Сухарлева. Харьков : Эспада, 2011. $352 c$.

3. Папакина Н.С., Н.В. Нежлукченко Экологическая безопасность овцеводства. Чисте місто. Чиста ріка. Чиста планета : збірник матеріалів форуму. Херсон:ХТПП, 2012. С. 347-351.

4. Програма селекції асканійської тонкорунної породи овець України на 2003-2010 роки / М-во аграр. Політики України., УААН, Держ. наук.-вироб. концерн «Селекція, корпорація Укр племзаводи, Національний Аграрний Університет. К., 2003. $39 \mathrm{c}$.

5. Трухачев В. И., Мороз В. А., М-С. М. Махдиев. К вопросу воспроизводства мериносов. Овцы, козы, шерстяное дело. 2010. № 3, С. 5-9.

6. Туринський В. М., Рябко В. М. Напрямки гормонізації вівчарства з природним середовищем південних степів України. Вісник ДДАУ. 2002. №2, С. 119-121.

7. Нежлукченко Т. І., Коваленко В. П., Шкарапата Я. Є., Лемеза І. С. Управління і моніторинг селекційними процесами у тваринництві при створенні високопродуктивних популяцій із використанням кращого світового генофонду. Таврійський науковий вісник. Херсон: Грінь Д.С., 2012. Вип. 78. Ч.2(1), С. 89-97.

8. Селекція сільськогосподарських тварин / [Мельник Ю.Ф., Коваленко В.П., Угнівенко А.М., Найденко К.А та інші]. К.: Iнтас, 2008. 445c.

9. Нежлукченко Н.В. Відтворювальні якості та адаптаційна здатність ліній овець таврійського типу асканійської тонкорунної породи: Автореф. дис. на здобуття наук. ступеня канд. с.-г. наук: спец. 06.02.01. Миколаїв, 2013. 20с.

10. Методические рекомендации по изучению качества шерсти: Москва, 1985.75 с.

11. Плохинский Н.А. Руководство по биометрии для зоотехников. М.: Колос, 1969. 247с.

\section{References:}

1. Krylova, O. and Zaruba, K., 2012. Askaniiska tonkorunna poroda, vnutriporodnyi typ [Askanian fine-woolen breed, intrabreed type]. Tvarynnytstvo Ukrainy, no. 8, pp. 42-45

2. Sukharlev, V. A. and Yakovlev, K. I., 2011. Sheep of Ukraine: [Monograph]. In: V.A. Sukharlev, ed. Khar'kov: Espada, pp. 352.

3. Papakina, N. S. and Nezhlukchenko, N. S., 2012. Ekologicheskaya bezopasnost' ovtsevodstva [Ecological safety of sheep breeding]. Chiste misto. Chista rika. Chista planeta: zbirnik materialiv forumu. Kherson: KhTPP, pp. 347-351. 
4. Prohrama selektsii askaniiskoi tonkorunnoi porody ovets Ukrainy na 2003-2010 roky [Program of selection of Askanian fine-wooled breed of sheep of Ukraine for 2003-2010]. 2003. M-vo ahrar. Polityky Ukrainy., UAAN, Derzh. nauk. - vyrob. Kontsern «Selektsiia, korporatsiia Ukr plemzavody, Natsionalnyi Ahrarnyi Universytet. Kyiv.

5. Trukhachev, V. I., Moroz, V. A. and Makhdiev, M-S. M., 2010. K voprosu vosproizvodstva merinosov [On the issue of reproduction of merino]. Ovtsy, kozy, sherstyanoe delo, no. 3, pp. $5-9$.

6. Turynskyi, V. M. and Riabko, V. M., 2002. Napriamky hormonizatsii vivcharstva z pryrodnym seredovyshchem pivdennykh stepiv Ukrainy [Directions of harmonization of sheep breeding with the natural environment of the southern steppes of Ukraine]. Visnyk DDAU, no. 2, pp. 119-121.

7. Nezhlukchenko, T. I., Kovalenko, V. P., Shkarapata, Ya. le. and Lemeza, I.S., 2012. Upravlinnia i monitorynh selektsiinymy protsesamy u tvarynnytstvi pry stvorenni vysokoproduktyvnykh populiatsii iz vykorystanniam krashchoho svitovoho henofondu [Management and monitoring of selection processes in animal husbandry in the creation of highly productive populations using the best global gene pool]. Tavriiskyi naukovyi visnyk. Kherson: Hrin D.S., issue 78 (2), pp. 89-97.

8. Melnyk, Yu. F., Kovalenko, V. P., Uhnivenko, A. M., Naidenko, K. A, [ta inshi]. 2008. Selektsiia silskohospodarskykh tvaryn [Breeding of farm animals]. K.: Intas, 445.

9. Nezhlukchenko, N. V., 2013. Reproductive qualities and adaptability of Taurian sheep lines of Askanian fine-wooled breed. Abstract of Ph.D. dissertation. Mykolaiv.

10. Metodicheskie rekomendatsii po izucheniyu kachestva shersti [Methodical recommendations for the study of wool quality]. 1985. Moskva.

11. Plokhinskiy, N. A., 1969. Rukovodstvo po biometrii dlya zootekhnikov [Biometrics guide for livestock technicians]. M.: Kolos, 247

Nezhlukchenko Tetiana Ivanivna, Doctor of Agricultural Sciences, Professor, Mykolayiv National Agrarian University (Mykolayiv, Ukraine)

Nezhlukchenko Natalia Valentynivna, PhD of Agricultural Sciences, State Enterprise "Askaniyske" Kakhovka district, (Kherson, Ukraine)

Zaruba Kostiantyn Vitaliiovych, PhD of Agricultural Sciences, Institute of Steppe Animal Husbandry named after M.F. Ivanova "Askania-Nova"

Rubtsov Ihor Alexandrovich, PhD of Agricultural Sciences, Docent, Sumy National Agrarian University (Sumy, Ukraine)

Formation of productive qualities of Askanian fine-wooled sheep of the Taurian type depending on the origin

Basic information on the patterns of growth and development of sheep and the formation of their productive qualities depending on their linear origin and the impact of heredity of breeding sheep. For the first time in the conditions of the breeding plant, depending on the linear origin, a comparative evaluation of sheep of the Askanian fine-wooled breed of the Taurian type on the indicators of growth, development and wool productivity was carried out. The genetic potential of lines on the basis of productivity and the degree of their implementation in the process of ontogenesis was determined. Wool productivity was observed in high and medium values in different sex and age groups of sheep, depending on their linear affiliation. Improvement of this indicator can be carried out with the maximum use in breeding of the sheep population of in-line combinations of animals of lines №227, 369, 375, $0517,1444$.

Key words: Askanian fine-woolen breed, Taurian type, growth, development, wool productivity, lines

Дата надходження до редакції: 08.12.2021 р. 